
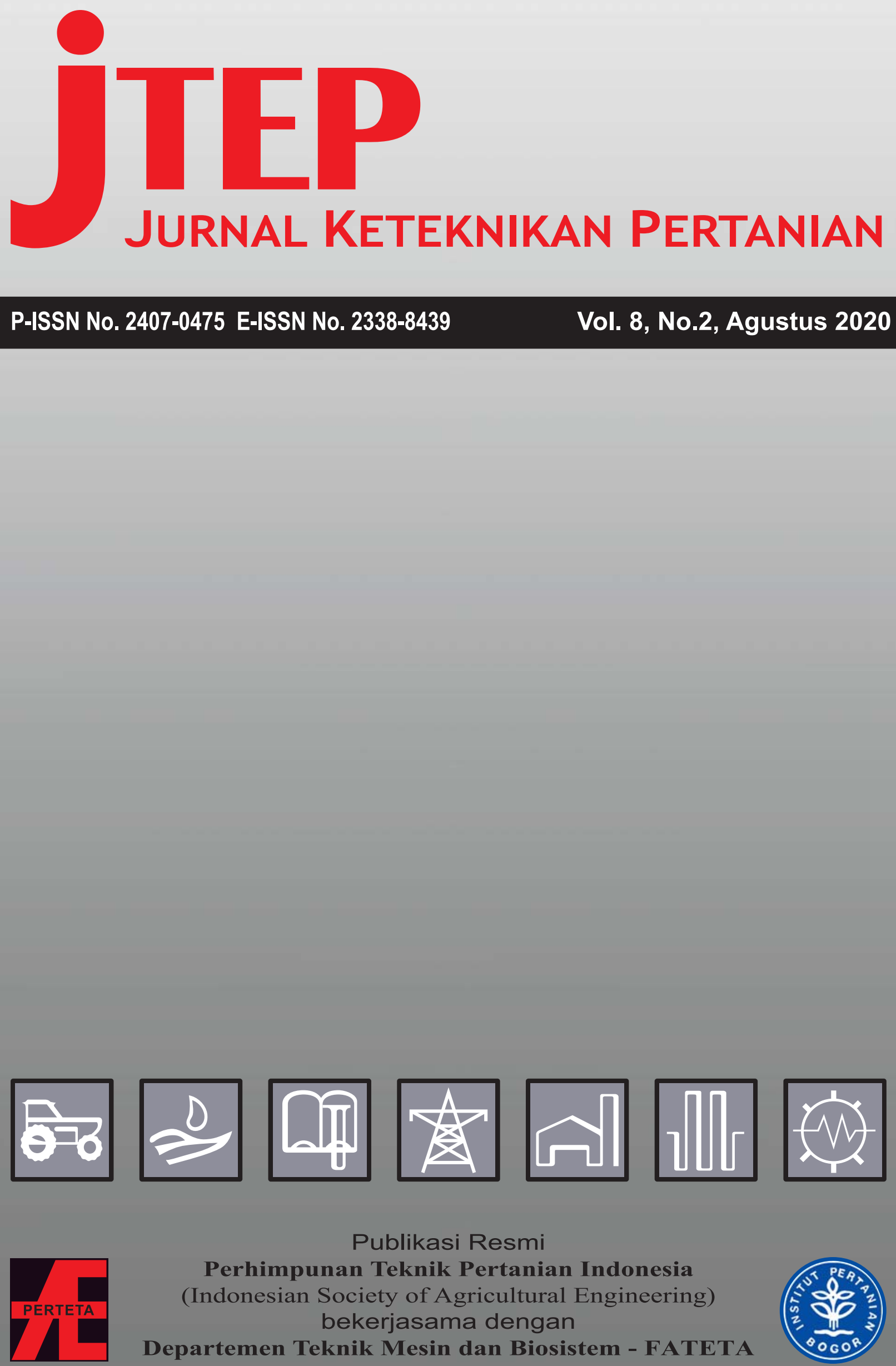

\footnotetext{
Publikasi Resmi

Perhimpunan Teknik Pertanian Indonesia (Indonesian Society of Agricultural Engineering) bekerjasama dengan

Departemen Teknik Mesin dan Biosistem - FATETA Institut Pertanian Bogor
} 


\section{jTEP JURnal Keteknikan Pertanian}

Vol. 8, No. 2, Agustus 2020

Jurnal Keteknikan Pertanian (JTEP) terakreditasi berdasarkan SK Dirjen Penguatan Riset dan Pengembangan Kementerian Ristek Dikti Nomor I/E/KPT/2015 tanggal 21 September 2015. Selain itu, JTEP juga telah terdaftar pada Crossref dan telah memiliki Digital Object Identifier (DOI) dan telah terindeks pada ISJD, IPI, Google Scholar dan DOAJ. JTEP terbit tiga kali setahun yaitu bulan April, Agustus dan Desember, Jurnal berkala ilmiah ini berkiprah dalam pengembangan ilmu keteknikan untuk pertanian tropika dan lingkungan hayati. Penulis makalah tidak dibatasi pada anggota PERTETA tetapi terbuka bagi masyarakat umum. Lingkup makalah, antara lain meliputi teknik sumberdaya lahan dan air, alat dan mesin budidaya pertanian, lingkungan dan bangunan pertanian, energi alternatif dan elektrifikasi, ergonomika dan elektronika pertanian, teknik pengolahan pangan dan hasil pertanian, manajemen dan sistem informasi pertanian. Makalah dikelompokkan dalam invited paper yang menyajikan isu aktual nasional dan internasional, review perkembangan penelitian, atau penerapan ilmu dan teknologi, technical paper hasil penelitian, penerapan, atau diseminasi, serta research methodology berkaitan pengembangan modul, metode, prosedur, program aplikasi, dan lain sebagainya. Penulisan naskah harus mengikuti panduan penulisan seperti tercantum pada website dan naskah dikirim secara elektronik (online submission) melalui http://journal.ipb.ac.id/index.php/jtep.

\section{Penanggungjawab:}

Ketua Departemen Teknik Mesin dan Biosistem, Fakultas Teknologi Pertanian,IPB

Ketua Perhimpunan Teknik Pertanian Indonesia

\section{Dewan Redaksi:}

Ketua : Yohanes Aris Purwanto (Scopus ID: 6506369700, IPB University)

Anggota : Abdul Hamid Adom (Scopus ID: 6506600412, University Malaysia Perlis)

(editorial Addy Wahyudie (Scopus ID: 35306119500, United Arab Emirates University)

board) Budi Indra Setiawan (Scopus ID: 55574122266, IPB University)

Balasuriya M.S. Jinendra (Scopus ID: 30467710700 , University of Ruhuna)

Bambang Purwantana (Scopus ID: 6506901423, Universitas Gadjah Mada)

Bambang Susilo (Scopus ID: 54418036400, Universitas Brawijaya)

Daniel Saputera (Scopus ID: 6507392012, Universitas Sriwjaya)

Han Shuqing (Scopus ID: 55039915600, China Agricultural University)

Hiroshi Shimizu (Scopus ID: 7404366016, Kyoto University)

I Made Anom Sutrisna Wijaya (Scopus ID: 56530783200, Universitas Udayana)

Agus Arif Munawar (Scopus ID: 56515099300, Universitas Syahkuala)

Armansyah H. Tambunan (Scopus ID: 57196349366, IPB University)

Kudang Boro Seminar (Scopus ID: 54897890200, IPB University)

M. Rahman (Scopus ID: 7404134933, Bangladesh Agricultural University)

Machmud Achmad (Scopus ID: 57191342583, Universitas Hasanuddin)

Muhammad Makky (Scopus ID: 55630259900, Universitas Andalas)

Muhammad Yulianto (Scopus ID: 54407688300, IPB University \& Waseda University)

Nanik Purwanti (Scopus ID: 23101232200, IPB University \& Teagasc Food Research Center Irlandia)

Pastor P. Garcia (Scopus ID: 57188872339 , Visayas State University)

Rosnah Shamsudin (Scopus ID: 6507783529, Universitas Putra Malaysia)

Salengke (Scopus ID: 6507093353, Universitas Hasanuddin)

Sate Sampattagul (Scopus ID: 7801640861, Chiang Mai University)

Subramaniam Sathivel (Scopus ID: 6602242315, Louisiana State University)

Shinichiro Kuroki (Scopus ID: 57052393500, Kobe University)

Siswoyo Soekarno (Scopus ID: 57200222075 , Universitas Jember)

Tetsuya Araki (Scopus ID: 55628028600, The University of Tokyo)

Tusan Park (Scopus ID: 57202780408, Kyungpook National University) 


\section{Redaksi Pelaksana:}

Ketua : : Usman Ahmad (Scopus ID: 55947981500, IPB University)

Sekretaris : Lenny Saulia (Scopus ID: 16744818700, IPB University)

Bendahara : Dyah Wulandani (Scopus ID: 1883926600, IPB University)

Anggota : Satyanto Krido Saptomo (Scopus ID: 6507219391, IPB University)

Slamet Widodo (Scopus ID: 22636442900, IPB University)

Liyantono (Scopus ID: 54906200300, IPB University)

Leopold Oscar Nelwan (Scopus ID: 56088768900, IPB University)

I Wayan Astika (Scopus ID: 43461110500, IPB University)

Agus Ghautsun Niam (Scopus ID: 57205687481, IPB University)

Administrasi : Khania Tria Tifani (IPB University)

Penerbit: Departemen Teknik Mesin dan Biosistem, Institut Pertanian Bogor bekerjasama dengan Perhimpunan Teknik Pertanian Indonesia (PERTETA).

Alamat: Jurnal Keteknikan Pertanian, Departemen Teknik Mesin dan Biosistem, Fakultas Teknologi Pertanian, Kampus Institut Pertanian Bogor, Bogor 16680.

Telp. 0251-8624 503, Fax 0251-8623 026,

E-mail: jtep@apps.ipb.ac.id

Website: http://journal.ipb.ac.id/index.php/jtep

Rekening: BRI, KCP-IPB, No.0595-01-003461-50-9 a/n: Jurnal Keteknikan Pertanian

Percetakan: PT. Binakerta Makmur Saputra, Jakarta 


\section{Ucapan Terima Kasih}

Redaksi Jurnal Keteknikan Pertanian mengucapkan terima kasih kepada para Mitra Bebestari yang telah menelaah naskah pada penerbitan Vol. 8, No. 2 Agustus 2020. Ucapan terima kasih disampaikan kepada: Dr. Leopold O. Nelwan, S.TP, M.Si (Departemen Teknik Mesin dan Biosistem, IPB University), Prof.Dr.Ir. Usman Ahmad, M.Agr (Departemen Teknik Mesin dan Biosistem, IPB University), Dr.Ir. Soni Solistia Wirawan, M.Eng (BPPT), Prof.Dr.Ir. Sutrisno M.Agr (Departemen Teknik Mesin dan Biosistem, IPB University), Ir. Siti Mariana Widayanti, M.Si, (Balai Besar Penelitian dan Pengembangan Pascapanen Pertanian), Dr.Ir. LilikPujantoro, M.Agr(Departemen TeknikMesin dan Biosistem, IPBUniversity). 
jiep Jurnal Keteknikan Pertanian 
Technical Paper

\title{
Integrasi Metode Gravitasi dan Metode Perbandingan Eksponensial untuk Penentuan Pusat Distribusi Pangan di Kabupaten Halmahera Selatan
}

\author{
Integration of Gravity Model and Exponential Comparison Methods for Determination of \\ Food Distribution Centers in South Halmahera Regency \\ Syamsul Bahri, Departemen Teknologi Pertanian, Universitas Khairun, Ternate. \\ Email: sbahri316@yahoo.com \\ Bambang Pramudya, Departemen Teknik Mesin dan Biosistem, IPB University.. \\ Email: bpramudya@yahoo.com \\ Sutrisno, Departemen Teknik Mesin dan Biosistem, IPB University.r. \\ Email: kensutrisno@yahoo.com \\ Emmy Darmawati, Departemen Teknik Mesin dan Biosistem, IPB University. \\ Email: darmawatihandono@gmail.com
}

\begin{abstract}
This study aims to determine the location of distribution centers in each island group in South Halmahera Regency. Data sources were obtained from survey results and literature studies. Integration of Gravity Models and Exponential Comparison Methods are used to determine the best location. Subdistrict of Kayoa as the location of distribution centers for Kayoa-Makian islands group, Subdistrict of West Gane for Gane islands group, Subdistrict of Bacan for Bacan-Kasiruta islands group, and the Obi Subdistrict for Obi Islands group. The location chosen as the distribution center in each island group is a main subdistrict which physically has better resource carrying capacity.
\end{abstract}

Keywords: Food, Islands, Distribution Centers

\begin{abstract}
Abstrak
Penelitian ini bertujuan untuk mengetahui lokasi pusat distribusi di setiap gugus pulau di Kabupaten Halmahera Selatan. Sumber data diperoleh dari hasil survei dan studi literatur. Integrasi Model Gravitasi dan Metode Perbandingan Eksponensial digunakan untuk menentukan lokasi terbaik. Kecamatan Kayoa sebagai lokasi pusat distribusi untuk gugus pulau Kayoa-Makian, Kecamatan Gane Barat untuk gugus pulau Gane, Kecamatan Bacan untuk gugus pulau Bacan-Kasiruta, dan Kecamatan Obi untuk gugus pulau Obi. Lokasi yang dipilih sebagai pusat distribusi pada masing-masing gugus pulau merupakan kecamatan induk yang secara fisik memiliki daya dukung sumber daya yang lebih baik.
\end{abstract}

Kata kunci: Pangan, Kepulauan, Pusat Distribusi

Diterima: 21 Januari 2020; Disetujui: 15 Juli 2020 


\section{Pendahuluan}

\section{Latar Belakang}

Ketahanan pangan merupakan satu kesatuan utuh atas dimensi ketersediaan, aksebilitas, dan stabilitas harga pangan (Arifin 2005). Dewan Ketahanan Pangan (DKP) bersama World Food Program (WFP) telah merumuskan indikatorindikator ketahanan pangan yang dikelompokkan ke dalam tiga faktor, yaitu faktor ketersediaan, akses, dan pemanfaatan pangan (DKP 2005).

Bagi wilayah dengan karakter kepulauan, jarak antar pulau dan antara pulau-pulau dengan pusat pemerintahan yang relatif jauh menyebabkan terjadinya kesenjangan kesejahteraan masyarakat, termasuk pendistribusian bahan pokok. (Alfenza dan Achmadi 2012). Pendistribusian bahan pokok pada pulau-pulau kecil di Indonesia lebih sulit karena setiap pulau memiliki kerawanan geografis dan aksesibilitas yang berbeda.

Perencanaan logistik yang baik sangat tergantung pada akurasi informasi menyangkut dinamika permintaan dan persediaan, sementara disisi lain responsivitas dan reliabilitas rantai pasokan pada wilayah kepulauan menjadi sangat rendah akibat jarak antar pulau dan sebarannya, karena itu sangat penting untuk membangun pusat distribusi (DC) yang berada pada setiap gugusan pulau. Alfenza dan Achmadi (2012) menggunakan metode Gravitasi untuk menentukan lokasi DC dengan menghitung daya tarik setiap lokasi berdasarkan luas wilayah, waktu tempuh dan kuantitas barang yang didistribusikan. Rekayasa algoritma Model Gravitasi digunakan Ama dkk (2015) untuk menentukan titip pusat gravitasi dalam menentukan lokasi lumbung pangan.

Penentuan lokasi DC pada setiap gugus pulau (GP) di Kabupaten Halmahera Selatan menggunakan integrasi Model Gravitasi dan Metode Perbandingan Eksponensial (MPE) dengan menambahkan kriteria sumberdaya dan infrastruktur pendukung.

\section{Tujuan Penelitian}

Penelitian ini bertujuan untuk menentukan lokasi pusat distribusi pangan pada masing-masing GP di Kabupaten Halmaheera Selatan

\section{Metode Penelitian}

Penelitian ini menggunakan metode survai berupa observasi dan wawancara terbatas dan dilaksanakan pada April hingga Juli 2017 di Kabupaten Halmahera Selatan Provinsi Maluku Utara.

Hasil pendugaan kebutuhan pangan perwilayah tiap periode tahun selanjutnya menjadi acuan untuk perencanaan strategis pengelolaan rantai pasok yang meliputi lokasi dan kapasitas fasilitas pergudangan, moda transportasi dan sistem informasi. Penentuan lokasi pusat distribusi pada setiap gugusan pulau dirancang dengan menggunakan Model Gravitasi yang diitegrasikan dengan Metode Perbandingan Eksponensial (MPE), dimana daya tarik setiap pulau/distrik merupakan fungsi dari luas area, demand dan jarak tempuh. Mengingat bahwa produk pangan yang didistribusikan bersifat mudah rusak maka ketersediaan sumberdaya dan infrastruktur logistik menjadi elemen fungsi yang menentukan daya tarik lokasi.

\section{Penentuan Titik Pusat Gravitasi}

Untuk menentukan koordinat pusat gravitasi pada masing-masing GP di Kabupaten Halmahera Selatan yaitu GP Kayoa-Makean, GP BacanKasiruta, GP Gane dan GP Obi digunakan model Gravitasi. Menurut Suthamphong (2012), model Gravitasi digunakan untuk menentukan lokasi terbaik yang merupakan titik temu antara demand and supply. Hal ini didasarkan pada jarak transportasi dan quantitas barang yang akan diangkut

Metode ini menggunakan paling sedikit 4 langkah yang harus dilakukan yaitu Pembuatan peta grid area, Identifikasi titik koordinat demand dan supply, Menetapkan kuantitas masing-masing titik koordinat, dan menghitung pusat gravitasi (Bozarth dan Handfield, 2006; Suthamphong, 2012). Persamaan matematik untuk metode Gravitasi adalah sebagai berikut:

$X_{c}=\frac{\sum Q_{i} D_{i} R_{i} X_{i}}{\sum Q_{i} D_{i} R_{i}}$

$Y_{c}=\frac{\sum Q_{i} D_{i} R_{i} Y_{i}}{\sum Q_{i} D_{i} R_{i}}$

Dimana:

$X_{c}=$ Koordinat titik $X$ dari pusat gravitasi.

$Y_{C}=$ Koordinat titik $Y$ dari pusat gravitasi.

$Q_{i}=$ Kuantitas barang yang diangkut pada setiap i tempat tujuan

$D_{i}=$ Jarak lokasi ke-i dari titik origin

$R_{i}=$ Biaya Angkut dari lokasi ke-i dari titik origin

$X_{i}=$ Titik koordinat lokasi ke-i dalam arah $\mathrm{X}$

$Y_{i}=$ Titik koordinat lokasi ke-i dalam arah $Y$.

Metode Gravity Location Model sendiri merupakan bagian dari strategi pengembangan jaringan Supply Chain Management yang digunakan untuk menentukan lokasi suatu fasilitas (misalnya gudang atau pabrik) yang menjadi penghubung antara sumber-sumber pasokan dan beberapa lokasi (Keller and Yeaple 2009). Menurut Anderson (2012), model gravitasi berkembang untuk mendukung perusahaan multi nasional dalam pengembangan transfer barang yang dimiliki, itu karena keunggulannya dalam analisis biaya transportasi yang bisa direduksi, selain itu Dasfordate (2012) menambahkan bahwa 
penggunaan teoritis gravitasi dalam praktek telah menyebabkan estimasi yang lebih akurat dan interpretasi lingkup spasial yang dijelaskan oleh gravitasi.

Selanjutnya dihitung jarak masing-masing lokasi alternatif pada setiap GP terhadap titik pusat gravitasi. Semakin dekat suatu lokasi terhadap titik pusat gravitasi, maka lokasi tersebut memiliki nilai prioritas yang tinggi, begitupun sebaliknya.

\section{Penentuan Lokasi Pusat Distribusi (DC)}

Untuk menentukan lokasi kecamatan yang akan dijadikan sebagai pusat distribusi pada masingmasing GP, digunakan Metode Perbandingan Eksponesnial (MPE) dengan kriteria berdasarkan jarak terhadap titik pusat gravitasi dan faktor pendukung (berupa infrastruktur pelabuhan, jalan, listrik, gudang).

MPE sangat cocok untuk penilaian skala ordinal (contoh sangat baik, baik, kurang, sangat kurang). Metode perbandingan eksponensial mempunyai keuntungan dalam mengurangi bias yang mungkin terjadi dalam analisis. Nilai skor yang menggambarkan urutan prioritas menjadi besar (fungsi eksponensial) ini mengakibatkan urutan prioritas alternatif keputusan lebih nyata (Marimin 2004).

Menurut Rangkuti (2011), Metode MPE ini mampu untuk menentukan urutan prioritas alternatif keputusan dengan menggunakan beberapa kriteria. Metode ini mampu mengurangi bias yang mungkin terjadi dalam analisis. Untuk nilai skor yang dihasilkan, akan mengambarkan urutan prioritas yang menjadi besar, ini mengakibatkan urutan prioritas alternatif keputusan menjadi lebih nyata. Selain itu metode ini merupakan salah satu metode pengambilan keputusan yang mengkuantifikasikan pendapat seseorang atau lebih dalam skala tertentu. Pada prinsipnya metode ini merupakan metode skoring terhadap pilihan yang ada. Dengan perhitungan secara eksponensial, perbedaan nilai antar kriteria dapat dibedakan tergantung kepada kemampuan orang yang menilai.

Langkah-langkah yang perlu dilakukan dalam pemilihan keputusan dengan MPE adalah: (1) penentuan alternatif keputusan; (2) penyusunan kriteria keputusan yang akan dikaji, (3) penentuan derajat kepentingan relatif setiap kriteria keputusan dengan menggunakan skala konversi tertentu sesuai keinginan pengambil keputusan, (4) penentuan derajat kepentingan relatif dari setiap alternatif keputusan dan (5) pemeringkatan nilai yang diperoleh dari setiap alternatif keputusan. Dalam perhitungan skor, formulasi untuk setiap alternatif pada metode MPE adalah:

Total Nilai $(T N i)=\sum_{j=1}^{m}(R K i j)^{T K K j}$

Total nilai I = total nilai akhir dari alternatif ke-i, RKij $=$ derajat kepentingan kriteria relatif ke-j pada pilihan
Tabel 1. Konsumsi rata-rata menurut kelompok barang makanan di Kabupaten Halmahera Selatan (diolah dari BPS Halsel 2014)

\begin{tabular}{lr}
\hline Jenis Pangan & g/kap-hari \\
\hline Beras & 165.62 \\
Jagung & 25.33 \\
Terigu & 35.00 \\
Umbi-umbian & 215.02 \\
Kacang-kacangan & 8.06 \\
Daging & 0.85 \\
Telur & 8.24 \\
Ikan & 56.79 \\
Susu & 8.24 \\
Sayuran & 68.04 \\
Buah & 27.67 \\
Lemak/minyak & 31.14 \\
\hline
\end{tabular}

keputusan $\mathrm{i}, \mathrm{TKKj}=$ derajat kepentingan kriteria relatif ke-j, TKK j > $0, \mathrm{~N}=$ jumlah pilihan keputusan dan $\mathrm{m}=$ jumlah kriteria keputusan.

\section{Hasil dan Pembahasan}

Besarnya konsumsi atau pengeluaran yang dilakukan oleh suatu rumah tangga menggambarkan tingkat kesejahteraan rumah tangga yang bersangkutan. Semakin tinggi pengeluaran yang dilakukan oleh suatu rumah tangga untuk kebutuhan bukan makanan, menunjukkan adanya peningkatan kesejahteraan rumah tangga bersangkutan. Sebagai ukuran, bila proporsi pengeluaran untuk makanan lebih dari 60 persen dari total pengeluaran, maka tingkat kesejahteraan dapat dikatakan masih rendah.

Secara garis besar, semakin tinggi proporsi pengeluaran yang digunakan untuk konsumsi makanan, maka pengeluaran untuk kesehatan, pendidikan, dan lainnya pun berkurang. Sebagaimana dilaporkan oleh Bahri at al. (2019) menunjukkan bahwa sumber energi utama untuk konsumsi pangan penduduk Halmaheraa Selatan adalah beras $(29.94 \%)$, umbi-umbian $(24.63 \%)$, dan ikan (16.12\%), produksi daerah sangat rendah (beras, minyak, kacang-kacangan) bahkan beberapa jenis pangan tidak diproduksi (terigu,telur, dan susu).

\section{Pusat Distribusi}

Pusat distribusi direncanakan terdapat pada setiap wilayah pengembangan yang disebut sebagai pengembangan gugus pulau yang terdiri dari 4 gugus pulau, karena itu akan ditentukan pula 4 pusat distribusi. Metode pusat Gravitasi digunakan untuk menentukan daya tarik masingmasing titik distribusi yang didasarkan pada data 
Tabel 2. Pusat Gravitasi untuk GP Makian-Kayoa menggunakan metode Gravitasi

\begin{tabular}{|c|c|c|c|c|c|c|c|c|c|c|c|}
\hline \multirow{2}{*}{ Kecamatan } & \multirow{2}{*}{$\begin{array}{c}\text { Jarak } \\
\text { tempuh } \\
\text { total (Di) }\end{array}$} & \multirow{2}{*}{$\begin{array}{c}\text { Biaya } \\
\text { Angkut } \\
\text { (Ri) }\end{array}$} & \multicolumn{2}{|c|}{ koordinat } & \multirow{2}{*}{$\begin{array}{c}\text { quantity } \\
\text { (Vi) }\end{array}$} & \multirow{2}{*}{$\begin{array}{l}\text { Pembagi } \\
\mathrm{Vi}^{*} \mathrm{Di}^{*} \mathrm{Ri}\end{array}$} & \multirow[b]{2}{*}{$V i^{*} X i^{*} D i^{*} R i$} & \multicolumn{3}{|c|}{ Koordinat } & \multirow{2}{*}{$\begin{array}{c}\text { Jarak dari } \\
\text { pusat } \\
\text { gravitasi }\end{array}$} \\
\hline & & & $\mathrm{x}$ & $y$ & & & & $\mathrm{Vi}^{*} \mathrm{Yi}^{*} \mathrm{Di}^{*} \mathrm{Ri}$ & $\mathrm{Y}$ & Koordinat X & \\
\hline Kayoa & 201 & 1005 & 589 & 572 & 509.85 & 102992021.3 & 60662300560 & 58911436197 & 340.85 & 586.87 & 21 \\
\hline Kayoa Selatan & 236 & 1180 & 605 & 641 & 411.52 & 114600212.3 & 69333128443 & 73458736086 & & & 26 \\
\hline Kayoa Utara & 192 & 960 & 638 & 414 & 196.16 & 36157104.2 & 23068232471 & 14969041133 & & & 10.5 \\
\hline Pulau Makian & 250 & 1250 & 597 & 71 & 551.15 & 172232845.2 & $1.02823 E+11$ & 12228532006 & & & 17 \\
\hline \multirow[t]{2}{*}{ Makian Barat } & 229 & 1145 & 498 & 124 & 252.75 & 66273529.4 & 33004217656 & 8217917649 & & & 17.5 \\
\hline & & & 586.87 & 340.85 & & 492255712.4 & $2.88891 E+11$ & 1.67786E+11 & & & 92 \\
\hline
\end{tabular}

Tabel 3. Nilai MPE untuk masing-masing Kecamatan untuk GP Kayoa-Makean.

\begin{tabular}{|c|c|c|c|}
\hline \multirow[b]{2}{*}{ Alternatif Lokasi } & \multicolumn{2}{|c|}{ Kriteria } & \multirow[b]{2}{*}{ Nilai MPE } \\
\hline & $\begin{array}{c}\text { Jarak terhadap PG } \\
9\end{array}$ & $\begin{array}{c}\text { faktor pendukung } \\
9\end{array}$ & \\
\hline Kayoa & 7.72 & 9 & $484,523,946.17$ \\
\hline Kayoa Selatan & 7.17 & 6 & $60,405,151.53$ \\
\hline Kayoa Utara & 8.86 & 8 & $470,209,028.33$ \\
\hline Pulau Makian & 8.15 & 7 & $199,376,966.63$ \\
\hline Makian Barat & 8.10 & 8 & $283,950,204.83$ \\
\hline
\end{tabular}

hasil estimasi kebutuhan pangan khususnya untuk komoditas beras serta jarak antar pulau. Komoditas beras dipilih dengan pertimbangan bahwa beras merupakan pangan pokok sumber karbohidrat yang paling banyak dikonsumsi.

Titik pusat distribusi untuk GP Kayoa-Makean berdasarkan hasil analisis diperoleh pada titik koordinat $X, Y(586.87$; 340.85), dan lokasi dengan jarak terdekat sebesar $10.5 \mathrm{~km}$ adalah kecamatan Kayoa Utara (Tabel 2).

Berdasarkan hasil pada Tabel 2, dengan menggunakan metode MPE, diperoleh lokasi dengan nilai MPE tertinggi adalah kecamatan Kayoa yaitu sebesar 484,523,946.17. Nilai

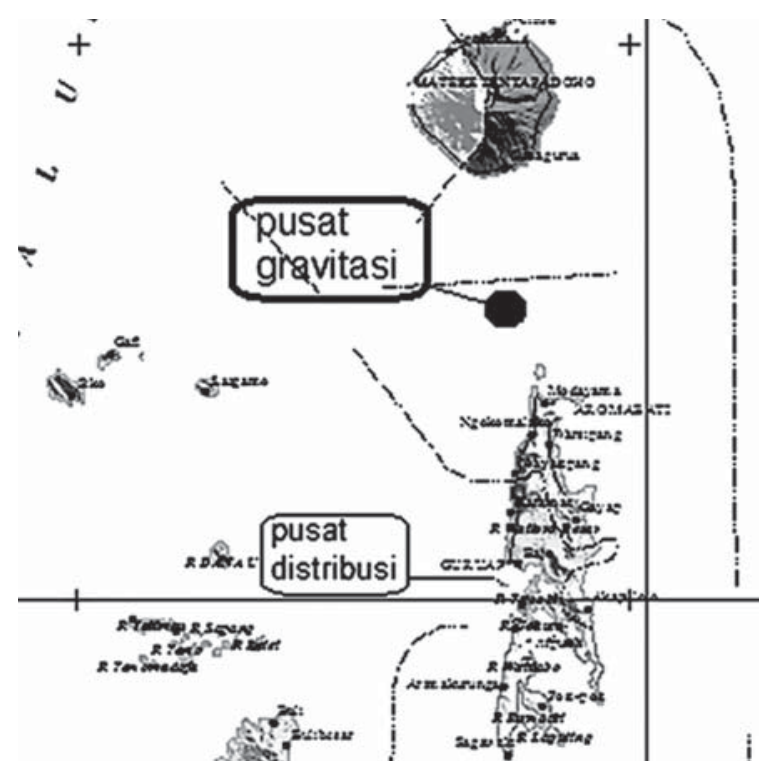

Gambar 1. Lokasi pusat gravitasi dan pusat. distribusi untuk GP Kayoa-Makean ini berimpit dengan kecamatan Kayoa Utara, meskipun berdasarkan kriteria jarak terdekat dari pusat gravitasi, Kecamatan Kayoa Utara memiliki nilai yang lebih tinggi namun Kecamatan Kayoa lebih unggul dari segi factor pendukung, sehingga Kecamatan Kayoa dapat ditetapkan sebagai lokasi pusat distribusi untuk GP Kayoa-Makean. Hasil analisis MPE selengkapnya pada Tabel 3 dan Gambar 1.

GP Bacan-Kasiruta merupakan GP terbesar yang terdiri dari 13 kecamatan. Terdiri dari tiga pulau sedang dan lainnya merupakan pulau-pulau kecil dan sebagian besar tidak berpenghuni. Lokasi pusat gravitasi untuk gugus Pulau Bacan-Kasiruta berdasarkan hasil analisis (Tabel 4) diperoleh pada titik koordinat $X, Y(330.50 ; 797.37)$, titik tersebut berada pada wilayah Kecamatan Bacan tetapi lebih dekat Kecamatan Batang Lomang (7.5 $\mathrm{km})$. Kecamatan Bacan dengan ibukota Labuha merupakan pusat pemerintahan dan perekonomian Kabupaten Halmahera Selatan.

Lokasi pusat distribusi untuk GP Bacan-Kasiruta, diperoleh lokasi dengan nilai MPE tertinggi adalah kecamatan Bacan yaitu sebesar 1,087,669,432.59. Meskipun berdasarkan kriteria jarak terdekat dari pusat gravitasi, Kecamatan Batang Lomang memiliki nilai yang lebih tinggi namun Kecamatan Bacan lebih unggul dari segi factor pendukung, sehingga Kecamatan Bacan dapat ditetapkan sebagai lokasi pusat distribusi untuk GP BacanKasiruta. Hasil analisis MPE selengkapnya pada Tabel 5 dan Gambar 2.

Pusat gravitasi untuk GP Obi berdasarkan hasil analisis diperoleh pada titik koordinat X, Y (486.54; 1379.74), dan wilayah dengan lokasi terdekat adalah kecamatan Obi dengan jarak 19 km (Tabel 
Tabel 4. Pusat Gravitasi untuk gugus pulau Bacan-Kasiruta menggunakan metode Gravitasi

\begin{tabular}{|c|c|c|c|c|c|c|c|c|c|c|c|}
\hline Kecamatan & $\begin{array}{c}\text { Jarak } \\
\text { tempuh } \\
\text { total (Di) }\end{array}$ & $\begin{array}{c}\text { Biaya } \\
\text { Angkut } \\
\text { (Ri) }\end{array}$ & $\begin{array}{l}\text { koor } \\
\mathrm{x}\end{array}$ & $\begin{array}{c}\text { linat } \\
y\end{array}$ & $\begin{array}{l}\text { quantity } \\
\text { (Vi) }\end{array}$ & $\begin{array}{l}\text { Pembagi } \\
\mathrm{Vi}^{*} \mathrm{Di}^{*} \mathrm{Ri}\end{array}$ & $\mathrm{Vi}^{*} \mathrm{Xi}^{*} \mathrm{Di}{ }^{*} \mathrm{Ri}$ & $V i{ }^{*}{ }^{\prime} i^{*} \mathrm{Di}^{*}{ }^{*} \mathrm{i}$ & $\begin{array}{c}\text { Koordinat } \\
Y\end{array}$ & $\begin{array}{c}\text { Koordinat } \\
\mathrm{X}\end{array}$ & $\begin{array}{l}\text { Jarak dari } \\
\text { pusat } \\
\text { gravitasi }\end{array}$ \\
\hline Bacan & 794 & 3970 & 387 & 838 & $1,671.76$ & 5269678225.3 & $2.03937 E+12$ & $4.41599 \mathrm{E}+12$ & 797.37 & 330.50 & 13 \\
\hline Mandioli Selatan & 1043 & 5215 & 254 & 930 & 414.86 & 2256529587.9 & $5.73159 \mathrm{E}+11$ & $2.09857 E+12$ & & & 18.4 \\
\hline Mandoli Utara & 880 & 4400 & 267 & 872 & 228.91 & 886353330.5 & $2.36656 \mathrm{E}+11$ & $7.729 \mathrm{E}+11$ & & & 28 \\
\hline Bacan Selatan & 847 & 4235 & 386 & 885 & $1,085.24$ & 3892817864.0 & $1.50263 \mathrm{E}+12$ & $3.44514 \mathrm{E}+12$ & & & 15.6 \\
\hline Kep Batang Lomang & 803 & 4015 & 329 & 835 & 436.02 & 1405736767.3 & $4.62487 \mathrm{E}+11$ & $1.17379 \mathrm{E}+12$ & & & 7.5 \\
\hline Bacan Timur & 934 & 4670 & 459 & 836 & 485.35 & 2116971863.4 & $9.7169 \mathrm{E}+11$ & $1.76979 \mathrm{E}+12$ & & & 26 \\
\hline Bacan Timur Selatan & 1151 & 5755 & 483 & 907 & 475.64 & 3150657889.4 & $1.52177 \mathrm{E}+12$ & $2.85765 \mathrm{E}+12$ & & & 36 \\
\hline Bacan Timur Tengah & 1344 & 6720 & 546 & 874 & - & 0.0 & 0 & 0 & & & 43 \\
\hline Bacan Barat & 881 & 4405 & 273 & 761 & 256.62 & 995888242.3 & $2.71877 E+11$ & $7.57871 \mathrm{E}+11$ & & & 16.5 \\
\hline Kasinta Barat & 1309 & 6545 & 166 & 663 & 327.24 & 2803611493.9 & $4.654 E+11$ & $1.85879 \mathrm{E}+12$ & & & 35.5 \\
\hline Kasinuta Timur & 1076 & 5380 & 246 & 661 & 219.50 & 1270651648.7 & $3.1258 \mathrm{E}+11$ & $8.39901 E+11$ & & & 27.4 \\
\hline Bacan Barat Utara & 1072 & 5360 & 370 & 702 & 310.39 & 1783489824.8 & $6.59891 \mathrm{E}+11$ & $1.25201 \mathrm{E}+12$ & & & 18 \\
\hline \multirow[t]{2}{*}{ Kayoa Barat } & 1500 & 7500 & 159 & 567 & 248.69 & 2797805192.0 & 4.44851E+11 & $1.58636 \mathrm{E}+12$ & & & 50 \\
\hline & & & & & & 28630191929.5 & $9.46235 \mathrm{E}+12$ & $2.28288 \mathrm{E}+13$ & & & 334.9 \\
\hline
\end{tabular}

Tabel 5. Nilai MPE untuk masing-masing Kecamatan untuk GP Kayoa-Makean

\begin{tabular}{lccc}
\hline \multirow{2}{*}{ Alternatif Lokasi } & \multicolumn{2}{c}{ Kriteria } & \multirow{2}{*}{ Nilai MPE } \\
\cline { 2 - 3 } & \multicolumn{1}{c}{ Jarak terhadap PG } & faktor & pendukung \\
\cline { 2 - 3 } & 9.61 & 9 & \\
\hline Bacan & 9.45 & 9 & $1,087,669,432.59$ \\
Mandioli Selatan & 9.16 & 6 & $611,427,399.70$ \\
Mandoli Utara & 9.53 & 6 & $465,837,130.97$ \\
Bacan Selatan & 9.78 & 7 & $691,313,061.42$ \\
Kep Batang Lomang & 9.22 & 7 & $855,943,335.82$ \\
Bacan Timur & 8.93 & 9 & $870,618,176.16$ \\
Bacan Timur Selatan & 8.72 & 6 & $369,410,534.02$ \\
Bacan Timur Tengah & 9.51 & 7 & $330,669,309.89$ \\
Bacan Barat & 8.94 & 6 & $644,708,581.06$ \\
Kasinta Barat & 9.18 & 7 & $405,132,613.53$ \\
Kasiruta Timur & 9.46 & 7 & $504,195,267.93$ \\
Bacan Barat Utara & 8.51 & 6 & $618,302,076.68$ \\
Kavoa Barat & & 6 & 243.421 .200 .07 \\
\hline
\end{tabular}

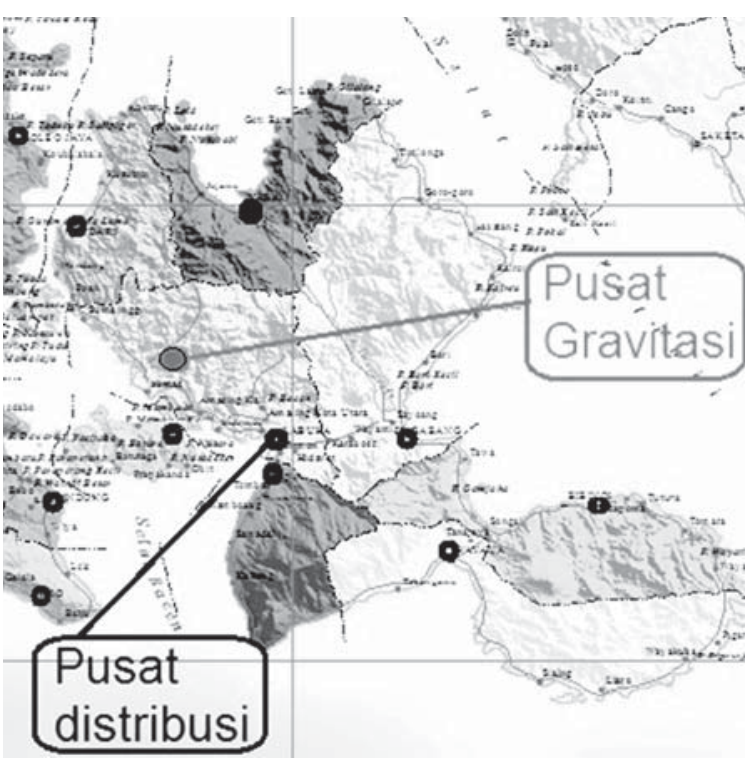

Gambar 2. Lokasi pusat gravitasi dan pusat distribusi untuk GP Bacan-Kasiruta.
6). Selanjutnya dengan menggunakan metode MPE, diperoleh lokasi dengan nilai MPE tertinggi adalah kecamatan Obi yaitu sebesar 724,635,732.46. Nilai ini sejalan metode gravitasi yang menempatkan kecamatan Obi sebagai lokasi terdekat dengan pusat gravitasi untuk GP Obi, sehingga Kecamatan Obi dapat ditetapkan sebagai lokasi pusat distribusi untuk GP Obi. Hasil analisis MPE selengkapnya pada Tabel 7 dan Gambar 3.

Pusat distribusi untuk GP Gane berdasarkan hasil analisis (Tabel 8), diperoleh pada titik koordinat $X, Y$ (721.52; 803.96), berada dalam wilayah kecamatan Gane Barat tetapi lebih dekat dengan Kecamatan Gane Timur Tengah (18 km). Lokasi dengan nilai MPE tertinggi adalah kecamatan Gane Barat yaitu sebesar 691,876,912.07. Meskipun berdasarkan kriteria jarak terdekat dari pusat gravitasi adalah Kecamatan Gane Timur Tengah, tetapi karena wilayah ini merupakan kecamatan hasil pemekaran, sehingga faktor pendukung untuk pembangunan dan pengembangan pusat distribusi masih kurang memadai. 
Tabel 6. Pusat Gravitasi untuk GP Obi menggunakan metode Gravitasi

\begin{tabular}{|c|c|c|c|c|c|c|c|c|c|c|c|}
\hline Kecamatan & $\begin{array}{c}\text { Jarak } \\
\text { tempuh } \\
\text { total (Di) }\end{array}$ & $\begin{array}{c}\text { Biaya } \\
\text { Angkut } \\
\text { (Ri) }\end{array}$ & $\begin{array}{c}\text { koor } \\
\mathrm{x}\end{array}$ & $\begin{array}{c}\text { dinat } \\
y\end{array}$ & $\begin{array}{l}\text { quantity } \\
\text { (Vi) }\end{array}$ & $\begin{array}{l}\text { Pembagi } \\
\mathrm{Vi}^{*} \mathrm{Di}^{*} \mathrm{Ri}\end{array}$ & $\mathrm{Vi}^{*} \mathrm{Xi}^{*} \mathrm{Di}{ }^{*} \mathrm{Ri}$ & $\mathrm{Vi}^{*} \mathrm{Yi}^{*} \mathrm{Di}{ }^{*} \mathrm{Ri}$ & $\begin{array}{c}\text { Koordinat } \\
\mathrm{Y}\end{array}$ & $\begin{array}{c}\text { Koordinat } \\
\mathrm{X}\end{array}$ & $\begin{array}{c}\text { Jarak dari } \\
\text { pusat } \\
\text { gravitasi }\end{array}$ \\
\hline$\overline{\text { Obi Selatan }}$ & 441 & 1000 & 462 & 1531 & 858.02 & 378385283.7 & $1.74814 E+11$ & $5.79308 \mathrm{E}+11$ & 1379.74 & 486.54 & 32 \\
\hline Obi & 294 & 1470 & 486 & 1285 & $1,017.27$ & 439645433.0 & $2.13668 \mathrm{E}+11$ & $5.64944 \mathrm{E}+11$ & & & 19 \\
\hline Obi Barat & 494 & 650 & 782 & 1428 & 258.26 & 82926137.0 & 64848239132 & 1. $18419 \mathrm{E}+11$ & & & 40 \\
\hline Obi Timur & 413 & 800 & 293 & 1315 & 240.31 & 79398464.3 & 23263750044 & $1.04409 \mathrm{E}+11$ & & & 51 \\
\hline Obi Utara & 338 & 500 & 491 & 1213 & 512.73 & 86651498.3 & 42545885669 & $1.05108 \mathrm{E}+11$ & & & 25 \\
\hline \multicolumn{6}{|c|}{1980} & 1067006816.33 & 519139556357.0 & 1.47219E+12 & & & 167 \\
\hline
\end{tabular}

Tabel 7 Nilai MPE untuk masing-masing Kecamatan untuk GP Obi

\begin{tabular}{lccc}
\hline \multirow{2}{*}{ Alternatif Lokasi } & \multicolumn{2}{c}{ Kriteria } & \multirow{2}{*}{ Nilai MPE } \\
\cline { 2 - 3 } & Jarak terhadap PG & faktor & pendukung \\
\cline { 2 - 3 } & 9 & 9 & \\
\hline Obi Selatan & 8.08 & 7 & $187,773,358.95$ \\
Obi & 8.86 & 9 & $724,635,732.46$ \\
Obi Barat & 7.60 & 8 & $219,289,454.80$ \\
Obi Timur & 6.95 & 7 & $77,995,691.28$ \\
Obi Utara & 8.50 & 6 & $242,429,933.57$ \\
\hline
\end{tabular}

Tabel 8. Pusat Gravitasi untuk gugus pulau Gane menggunakan metode Gravitasi

\begin{tabular}{|c|c|c|c|c|c|c|c|c|c|c|c|}
\hline Kecamatan & $\begin{array}{c}\text { Jarak } \\
\text { tempuh } \\
\text { total (Di) }\end{array}$ & $\begin{array}{c}\text { Biaya } \\
\text { Angkut } \\
\text { (Ri) }\end{array}$ & $\begin{array}{c}\text { koor } \\
\mathrm{x} \\
\end{array}$ & $\begin{array}{c}\text { dinat } \\
y \\
\end{array}$ & $\begin{array}{c}\text { quantity } \\
\text { (Vi) }\end{array}$ & $\begin{array}{l}\text { Pembagi } \\
\mathrm{Vi}^{*} \mathrm{Di}^{*} \mathrm{Ri}\end{array}$ & $\mathrm{Vi}^{*} \mathrm{Xi}^{*} \mathrm{Di}^{*} \mathrm{Ri}$ & $\mathrm{Vi}^{*} \mathrm{Yi}^{*} \mathrm{Di}{ }^{*} \mathrm{Ri}$ & $\begin{array}{c}\text { Koordinat } \\
\mathrm{Y} \\
\end{array}$ & $\begin{array}{c}\text { Koordinat } \\
\mathrm{X}\end{array}$ & $\begin{array}{c}\text { Jarak dari } \\
\text { pusat } \\
\text { gravitasi }\end{array}$ \\
\hline Gane Barat & 648 & 3240 & 617 & 667 & 486.47 & 1021345693.0 & $6.3017 \mathrm{E}+11$ & $6.81238 \mathrm{E}+11$ & 803.96 & 721.52 & 38 \\
\hline Gane Barat Selatan & 554 & 2770 & 848 & 924 & 386.99 & 593869884.3 & $5.03602 E+11$ & $5.48736 \mathrm{E}+11$ & & & 32 \\
\hline Gane Barat Utara & 824 & 4120 & 517 & 607 & 334.93 & 1137046745.2 & $5.87853 E+11$ & $6.90187 \mathrm{E}+11$ & & & 57 \\
\hline Kep Joronga & 786 & 3930 & 910 & 1039 & 372.55 & 1150797835.4 & $1.04723 E+12$ & $1.19568 \mathrm{E}+12$ & & & 51 \\
\hline Gane Timur & 996 & 4980 & 642 & 406 & 0 & 0 & 0 & 0 & & & 82 \\
\hline Gane Timur Tengah & 532 & 2660 & 746 & 711 & 54.31 & 76850732.3 & 57330646273 & 54640870643 & & & 18 \\
\hline Gane Timur Selatan & 532 & 2660 & 849 & 886 & 251.64 & 356102466.4 & $3.02331 \mathrm{E}+11$ & $3.15507 \mathrm{E}+11$ & & & 29 \\
\hline
\end{tabular}

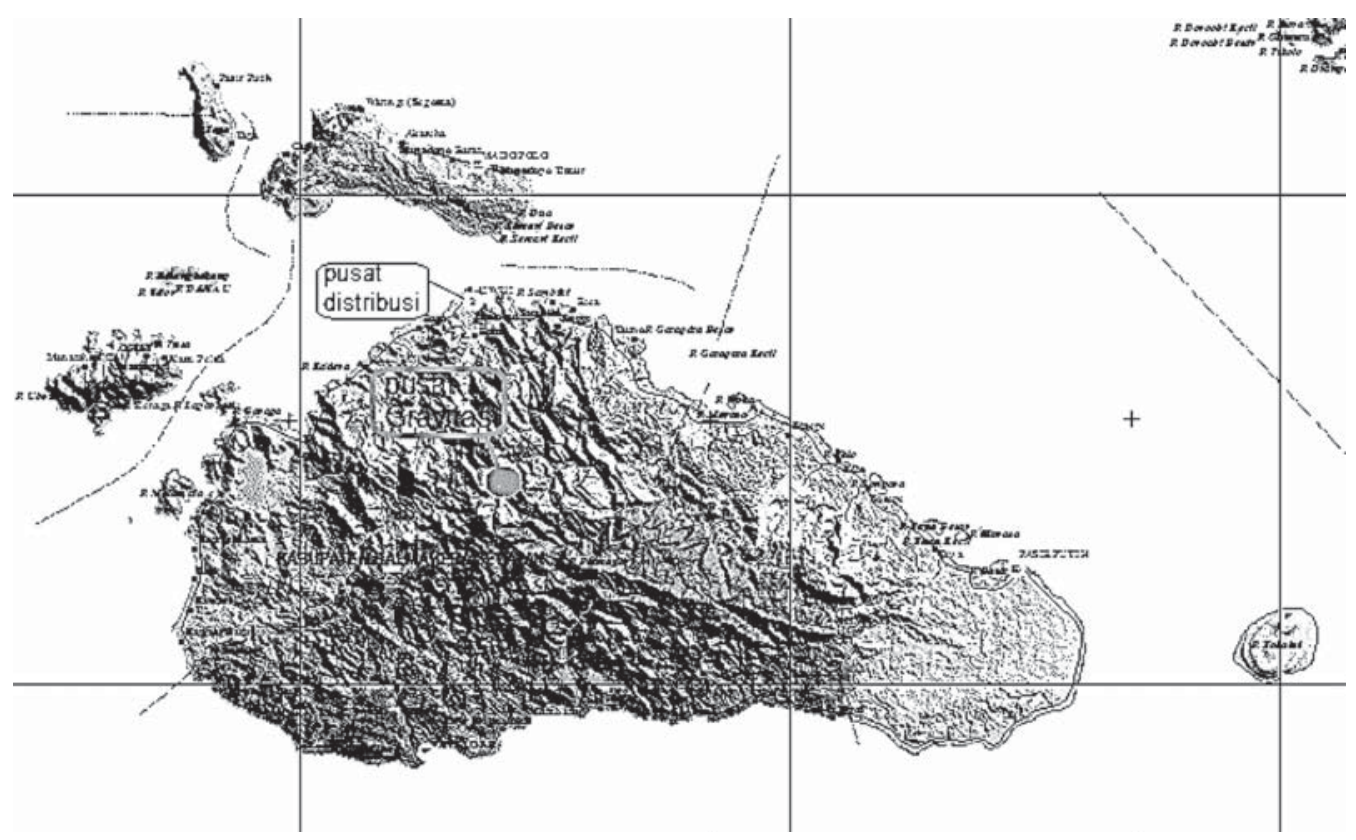

Gambar 3. Lokasi pusat garvitasi dan pusat distribusi untuk GP Obi. 
Tabel 7 Nilai MPE untuk masing-masing Kecamatan untuk GP Obi

\begin{tabular}{lccc}
\hline \multirow{2}{*}{ Alternatif Lokasi } & \multicolumn{2}{c}{ Kriteria } & \multirow{2}{*}{ Nilai MPE } \\
\cline { 2 - 3 } & \multicolumn{1}{c}{ Jarak terhadap PG } & faktor & \\
\cline { 2 - 3 } & 8.76 & 9 & $691,876,912.07$ \\
Gane Barat & 8.96 & 9 & $381,398,143.50$ \\
Gane Barat Selatan & 8.14 & 6 & $197,829,724.44$ \\
Gane Barat Utara & 8.34 & 7 & $205,023,687.01$ \\
Kep Joronga & 7.33 & 6 & $195,227,202.42$ \\
Gane Timur & 9.41 & 8 & $620,897,693.34$ \\
Gane Timur Tengah & 9.06 & 7 & $449,762,982.65$ \\
Gane Timur Selatan & & 7 & \\
\hline
\end{tabular}

Faktor pendukung yang cukup justru dimilki oleh Kecamatan Gane Barat, yang memang sjak awal sudah merupakan kecamatan induk bahkan ketika Provinsi Maluku Utara masih bagian administrative dari Provinsi Maluku. Dengan demikian Kecamatan Gane Barat dapat ditetapkan sebagai lokasi pusat distribusi untuk GP Gane. Hasil analisis MPE selengkapnya pada Tabel 9 dan Gambar 4.

Pusat distribusi pada masing-masing GP yang ditentukan berdasarkan pendekatan model gravitasi yang diintegrasikan dengan metode perbandingan eksponensial dianggap lebih proporsional terhadap berbagai parameter terkait kepentingan dan daya dukung sumberdaya. Harding (1978) dan Alcacer (2006) mengidentifikasi bahwa ketersediaan sumberdaya (sumber alam, tenaga kerja, transportasi, pembangkit tenaga serta ketersediaan tanah untuk perluasan usaha) merupakan faktor penting dalam menentukan lokasi. Bahkan Fu'ad (2015) menegaskan bahwa 49\% keberhasilan pengembangan usaha ditentukan oleh daya dukung lingkungan dan sumberdaya.

Lokasi yang terpilih sebagai pusat distribusi pada setiap GP sebagian besar merupakan kecamatan induk yang pada dasarnya secara fisik memiliki daya dukung sumberdaya yang lebih baik.

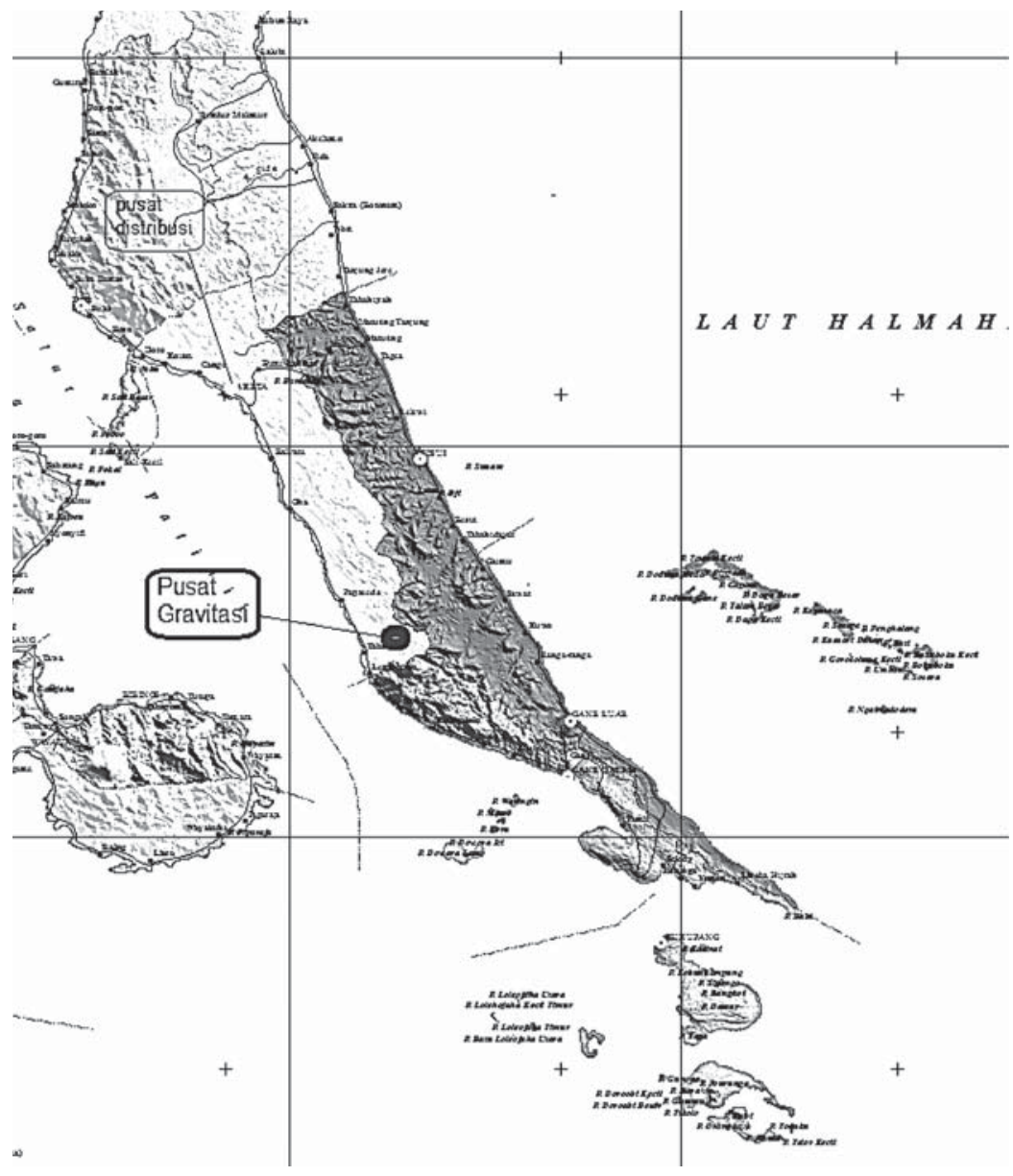

Gambar 4. Lokasi Pusat Garvitasi dan Pusat Distribusi Untuk GP Gane. 


\section{Simpulan}

Hasil estimasi kebutuhan pangan menjadi acuan dalam menentukan pusat distribusi pada masing-masing gugus pulau. Pusat distribusi pada masing-masing GP yang ditentukan berdasarkan pendekatan model gravitasi yang diintegrasikan dengan metode perbandingan eksponensial dianggap lebih proporsional terhadap berbagai parameter terkait kepentingan dan daya dukung sumberdaya.

Kecamatan Kayoa sebagai lokasi pusat distribusi untuk GP Kayoa-Makean, Kecamatan Gane Barat untuk GP Gane, Kecamatan Bacan untuk GP Bacan-Kasiruta, dan Kecamatan Obi untuk GP Obi. Lokasi yang terpilih sebagai pusat distribusi pada setiap GP sebagian besar merupakan kecamatan induk yang pada dasarnya secara fisik memiliki daya dukung sumberdaya yang lebih baik.

\section{Daftar Pustaka}

Alfenza, T.F. dan T. Achmadi. 2012. Penentuan Pola dan Pusat Distribusi Bahan Pokok untuk Wilayah Berbasis Kepulauan. Jurnal Teknik ITS Vol. 1.

Alcacer, J. 2006. Location Choices Across the Value Chain: How Activity and Capability Influence Collocation. Management Science, 52, 1457-1471.Anderson JE. 2012. A Theoretical Foundation for the Gravity Equation. Am. Econ. Assoc., vol. 69, no. 1, pp. 106-116, 2012.

Ama, A.U.T, E. Sediyono, A. Setiawan. 2015. Rekayasa Algoritma Gravity Location Models Untuk Penentuan Lokasi Lumbung Pangan Masyarakat Kabupaten Minahasa Tenggara. Jurnal Teknik Informatika dan Sistem Informasi Volume 1 Nomor 3, p. 194-202.

Andika, D. 2011. Berbagai Teori Lokasi. https://www. siswandikha.blogspot. com/2011/12/ berbagaiteori-lokasi.html. diakses tanggal 27 Juni 2014

Anindita, Y. 2014. Model Analisis Kependudukan Dalam Perencanaan Lingkungan. https://www. academia.edu/3805234. diakses tanggal 22 Oktober 2014

Arifin, B. 2005. Ekonomi Kelembagaan Pangan. Pustaka LP3ES. Jakarta

[BPS] Badan Pusat Statistik Halmahera Selatan, 2014. Dokumen Strategis Daerah Kabupaten Halmahera Selatan: DDA, Inkesra, RAD dan Idikator Ekonomi Daerah.
Bozarth, C.C. and R.B. Handfield. 2006. Introduction to Operations and Supply Chain Management. Student Value Edition. New Jersey: Pearson/ Prentice Hall Inc. $3^{\text {th }}$ edition.

Dasfordate, M.T. 2012. Penentuan Alternatif Lokasi Gudang Akhir Rumput Laut Dengan Metode Center of Gravity Dan Point Rating (Studi Kasus di Kabupaten Seram Bagian Barat), ARIKA, vol. 06, no. 2, p. 115-124.

Fu'ad, E.N. 2015. Pengaruh Pemilihan Lokasi Terhadap Kesuksesan Usaha Berskala Mikro/ Kecil Di Komplek Shopping Centre Jepara. MEDIA EKONOMI DAN MANAJEMEN Vol. 30 No. 1, p. 56-67.

Harding, H.A. 1978. Manajemen Produksi. Balai Aksara, Jakarta

Keller, W. and S.R. Yeaple. 2009. Gravity in the Weightless Economy. seminar participants paper at the 2009 NBER ITO conference, Colorado.

Marimin, 2004. Teknik dan Aplikasi Pengambilan Keputusan Kriteria Majemuk. Jakarta. Grasindo

Muammil, S., S. Bahri dan Marwan. 2013. Analisis Situasi Kini Ketersediaan Pangan di Kepulauan Halmahera Selatan. Laporan Hasil Penelitian MP3EI kerjasama Dirjen Dikti Kementerian Pendidikan Nasional, Bappeda Maluku Utara dan LPPM Unkhair.

Rangkuti, A.H. 2011. Teknik Pengambilan Keputusan Multi Kriteria Menggunakan Metode Bayes, MPE, CPI, dan AHP. ComTech Vol.2 No. 1: p. 229-238.

Ridwan, T.A., S. Supriatna dan E.Y. Purwani. 2008. Simulasi Model Dinamik Ketersediaan Sagu Mendukung Ketahanan Pangan: Kasus Papua. Prosiding Seminar Nasional Teknologi Inovatif Pascapanen untuk Pengembangan Industri Berbasis Pertanian Balai Besar Penelitian dan Pengembangan Pascapanen Pertanian.

Snyder, L.V., M.S. Daskin and C.P. Teo. 2007. The Stochastic Location Model with Risk Pooling. Final version published 179(3), p. 1221-1238

Suthamphong, A. 2012. Identifying an Optimal Facility Location for a Factory. Project report for the degree of MSc in supply chain management. Department Of Industrial Management, Assumption University.

Yunitasari, E.W. 2015. Metode Gravity Location Models dalam Penentuan Lokasi Cabang yang Optimal di PT. ABC. Tekinfo - Jurnal Ilmiah Teknik Industri dan Informasi, 3(2): 75-82. 